THE KAI COGNITIVE STYLE INVENTORY:

WAS IT PERSONALITY ALL ALONG?

\begin{abstract}
Daniel von Wittich \& John Antonakis* Department of Organizational Behavior Faculty of Business and Economics University of Lausanne
\end{abstract}

in press

"Personality and Individual differences"

January 2011

*Corresponding author:

Internef \#618

CH-1015 Lausanne-Dorigny

Switzerland

Tel ++41 (0)21 692-3438

E-mail: john.antonakis@unil.ch 


\section{THE KAI COGNITIVE STYLE INVENTORY: WAS IT PERSONALITY ALL ALONG?}

Kirton's Adaption-Innovation Inventory (KAI) is a widely-used measure of "cognitive style." Surprisingly, there is very little research investigating the discriminant and incremental validity of the KAI. In two studies ( $n=213$ ), we examined whether (a) we could predict KAI scores with the "big five" personality dimensions and (b) the KAI scores predicted leadership behavior when controlling for personality and ability. Correcting for measurement error, we found that KAI scores were predicted mostly by personality and gender (multiple $R=.82$ ). KAI scores did not predict variance in leadership while controlling for established predictors. Our findings add to recent literature that questions the uniqueness and utility of cognitive style or similar "style" constructs; researchers using such measures must control for the big five factors and correct for measurement error to avoid confounded interpretations.

Keywords: Cognitive style; personality; KAI; adaptors-innovators; NEO-PI; psychometrics; leadership; measurement error. 


\section{Introduction}

It is well established that personality and cognitive ability are reliable predictors of behaviors and outcomes in various domains. Attempts have been made to complement conventional models with cognition and information-processing "styles." Research in this area has proliferated and many inventories have recently emerged (Kozhevnikov, 2007; Riding, 1997).

Examples of these "style" or "type" models include cognitive emotions or styles and thinking or learning styles to mention a few (see Kirton, 1976; Kolb \& Kolb, 2005; Scheffler, 1991; Sternberg, 1988). Many of these models are but different conceptualizations of similar concepts (Riding, 1997). More troubling, however, is that the discriminant properties of these models have not been investigated (Kozhevnikov, 2007); thus, the use of these inventories in practice is problematic, particularly in light of certain commercial interests (cf. Pashler, McDaniel, Rohrer, \& Bjork, 2008).

We sought to determine how one popular cognitive style measure, the Kirton AdaptationInnovation inventory, KAI, (Kirton, 1976), fits into the nomological network of individual differences. We sought to answer the following two questions: Does cognitive style discriminate from established individual-difference measures (i.e., personality)? Does cognitive style predict outcomes to which it should be theoretically linked (e.g., leadership) when controlling for personality and ability? We examined these questions in two studies using a multi-point crosssectional design.

\section{The KAI: An Established Measure of What, Precisely?}

The KAI apparently measures differences in problem-solving "preferences" (Kirton, 1976, 1999, 2003) and individuals can be located on a continuum ranging from being "adaptive" to "innovative." Since its appearance, the KAI has received considerable attention. Kirton's 1976 
article has received well over 400 citations in Thompson's Web of Science (WOS). Almost half of these citations emanated from the last decade. A simple internet search also shows that the KAI is used by many practitioners for a variety of industrial and applied purposes.

In terms of the psychometric properties of the KAI, Kirton (1976) reported that it has good reliability and that it only correlates with extraversion (i.e., .37); however, the KAI was only compared to two dimensions of personality, extraversion and neuroticism. Later, Tullett and Kirton (1995) stated that the KAI is only related to extraversion (with $r$ 's between .16 to .46, depending on the inventory). These results are limited in that the multivariate relation of personality with the KAI was ignored as were the effects of measurement error, which can severely bias estimates (Antonakis \& Dietz, 2011).

Because proponents of the theory suggest that the KAI does not measure personality, researchers have not been concerned to control for personality when using it (cf. Kozhevnikov's (2007). As a check, we reviewed articles listed in the WOS that cited Kirton's (1976) paper up until 2009. We only considered empirical articles that used the original items of the KAI and some dependent outcome. Also, to ensure that the articles we reviewed were from solid journals, we used only journals whose impact factors were greater than the mean impact factor in the category in which the journal is listed (based on the WOS's 2007 Journal Citations Report). Surprisingly, none of the 15 studies we identified controlled for the big five (see Appendix). Two studies did administer the MBTI (Myers-Briggs Type Indicator)--whose psychometric properties have been strongly criticized (e.g., Pittenger, 1993)--though they did not control for it in their analyses.

If the KAI overlaps substantially with established measures of personality, the results of the studies included in the appendix are questionable (as are all other studies not controlling for 
personality in other journals). This void in the literature provided us with the impetus to examine the discriminant and incremental validity of the KAI.

\section{The KAI: Seems like Personality}

For Kirton $(1976,1999,2003)$, adaptive individuals tend to be compliant, methodical, prudent, disciplined, conforming, timid in ideation, high self-doubters, sensitive to people, risk averse, and dogmatic. Innovators tend to be assertive, impractical, unconventional in their thinking, undisciplined, irreverent toward consensual views, nonconforming, bold in ideation, low self-doubters, insensitive to people, risk seeking, flexible, and abrasive. Given these descriptions, there may be substantial overlap between the KAI and five factor model.

We expected individuals who score high on extraversion and openness to new experiences to have an innovative style given that these individuals are assertive, dominant, daring, as well as creative, imaginative, inquisitive, unconventional, nonconforming and risktakers. Moreover, they are very self-assured, do not shy away from novel situations, embrace change and like to generate ideas (cf. Costa \& McCrae, 1992).

Individuals high on agreeableness, neuroticism, and conscientiousness are likely to have a more adaptive style; agreeable individuals generally accept the status quo, follow rules, avoid conflict and tend to be considerate, compliant, and understanding (cf. Costa \& McCrae, 1992). Furthermore, conscientious individuals are disciplined, orderly, cautious, dutiful, and deliberate (cf. Costa \& McCrae, 1992): individuals high on neuroticism tend to be, among other things, socially shy, inhibited, self-conscious, and dependent (cf. Costa \& McCrae, 1992).

\section{KAI and Leadership}

Researchers have begun to link "style" to outcomes, including leadership (Sadler-Smith, 1998). Theoretically leaders who are change-oriented, visionary and inspiring (i.e., 
transformational leaders, Bass, 1985) should be innovators. Those who are more stability focused--who clarify role and task requirements and ensure that standards are met (i.e., transactional leaders, Bass, 1985)--should be adaptors. Innovators are more likely to be perceived as transformational leaders (Church \& Waclawski, 1998). Being innovative is positively and significantly associated with two of five factors of the Kouzes and Posner Leadership Practices Inventory (Isaksen, Babij, \& Lauer, 2003).

These studies are limited, however, in that they used self-evaluations of leadership or leadership models with unknown psychometric properties. Given the limitations of the studies above, we examined if KAI scores predicted a well validated measure of leadership when controlling for the big five personality dimensions.

\section{Method}

\section{Participants}

We recruited 213 Bachelor of Science in Economics-Management students (37.61\% female; age $=20.89$ years) enrolled in an organizational behavior course at a business school of a state university in Switzerland; students participated for course credit. We gathered data in several stages over the semester for the two studies (to limit bias associated with commonmethod variance).

\section{Study 1}

Procedure: Participants first completed the measure of cognitive style. Ten days later we instructed them to complete a personality questionnaire. Finally, seven weeks later, we administered a test of cognitive ability (IQ).

Measures: We administered the following three official French versions of the tests: (a) The Kirton's Adaption-Innovation Inventory (32 self-rated items using a 1-5 point scale, alpha = 
.88, Kirton, 1999), (b) the NEO Personality Inventory (240 self-rated items using a 0-4 point scale, alphas ranging from .68 to .83, Costa \& McCrae, 1992), and (c) IQ using the Wonderlic Personnel Test (which correlates from between .75 to .96 with the Wechsler Adult Intelligence Scale, Wonderlic, 2002).

Data Analysis: We regressed the KAI scores on the personality and control variables (participant's gender, age, nationality, French language, and IQ). We estimated two regression models, an ordinary least squares regression model, and an errors-in-variables (EIV) least squares model (using Stata) wherein we modeled measurement error (cf. Bollen, 1989). Note that apart from attenuating coefficient estimates, measurement error also biases coefficient estimates in correlated covariates (Antonakis, Bendahan, Jacquart, \& Lalive, 2010).

\section{Study 2:}

Procedure: In addition to the data from Study 1, we also gathered data on the leadership ability on a subset of participants $(n=53)$. Between the administration of the personality and IQ tests participants partook in a three-member group decision-making task regarding a business investment decision. We randomly appointed one participant as a leader to coordinate the efforts of the other two group members (we also randomly assigned between one to two participants to each group to act as observers). The leader's goal was to promote effective interaction between group members; thus, the nature of the exercise was such that we could obtain measures of leadership ability of the appointed leader (rated by the group members and observes, $n=160$ ).

Measures: In addition to the measures from Study 1, we gathered data on the leaders using a French version (available from the publishers) of the MLQ, Multifactor Leadership Questionnaire (Bass \& Avolio, 1995). This is the most-used (Judge \& Piccolo, 2004) and bestvalidated measure of transformational-transactional leadership (Antonakis, Avolio, 
Sivasubramaniam, 2003). It includes (a) twenty transformational leadership items reflecting a visionary, challenging, and inspirational form of leadership (alpha $=.80)$, (b) four contingent rewards items measuring structuring and rewarding transactional leadership (alpha $=.60)$, (c) four management-by-exception active items gauging corrective transactional leadership (alpha = .72). The group leader was the only target of the leadership ratings and we only used the ratings of the team members and of the observers, and not the leader self-ratings because the latter are biased and self-serving (Podsakoff \& Organ, 1986).

Data Analysis: We regressed the leadership ratings regarding the target leaders on their KAI, personality scores, and control variables. Because ratings on the three leadership dimensions were (a) correlated and (b) observations within groups were not independent (i.e., raters $i$ nested in leader groups $j$ ) we allowed the disturbances of the leader dimensions to correlate; we also corrected standard errors for group clustering (and modeled the variables as latent) using the Mplus program.

\section{Results}

\section{Study 1: Discriminant validity}

Refer to Table 1 for interfactor correlations and descriptive statistics.

[Insert Table 1 here]

Whether using the ordinary least squares (OLS) or the errors-in-variable (EIV) estimator, the KAI scores depended largely on personality (see Table 2). As we hypothesized, an innovative style was positively predicted by extraversion and openness, and negatively predicted by neuroticism, agreeableness, and conscientiousness.

[Insert Table 2 here] 
The variance accounted for by the OLS estimator was very large $50.45 \%$ (multiple $R$ of .71); however, $r$-square accounted for by the EIV estimator was larger, 66.54\% (multiple $R$ of

.82). Partial standardized regression coefficients for Neuroticism, Extraversion, Openness, Agreeableness, and Conscientiousness were, respectively, -..40, .30, .40, -.52, -.56, which are hardly trivial. For an idea of the bias presented in the OLS estimator, the EIV estimates were different from the OLS estimates to the following respective margin: $+37.93 \%,+11.11 \%$, $+42.86 \%,-52.94 \%,-30.23 \%$. For gender, the difference was $+116.67 \%$. The average absolute bias across these coefficients was to the order of $48.62 \%$. When compared to the zero order correlations the EIV estimates were different as follows (respectively): $-73.91 \%,+23.08 \%$, $2.44 \%,-79.31 \%,-69.70 \%$ (for gender the difference was $+200.00 \%$ ); the average absolute bias, which is $74.74 \%$, is even more dramatic. These results underscore the importance of conducting discriminant validity tests in a multivariate manner and to account for measurement error (Antonakis et al., 2010; Antonakis \& Dietz, 2011; Schulte, Ree, \& Carretta, 2004).

\section{Study 2: Incremental validity}

Refer to Table 3 for descriptive statistics and correlations among the key variables.

$$
\text { [Insert Table } 3 \text { here] }
$$

Before including the KAI scores in the model, results indicated that leader conscientiousness significantly predicted transformational leadership, standardized $\beta=.19(p<$ $.05)$; model $r$-square $=.10, p<.05$. Leader conscientiousness also predicted contingent reward leadership, standardized $\beta=.25(p<.05)$; model $r$-square $=.10, p<.01$. Finally, for management-by-exception active, leader agreeableness was a significant predictor: $\beta=-.25(\mathrm{p}<$ $.10)$; model $r$-square $=.09, p<.05$. Adding the KAI scores to the model did not significantly improve the model; the KAI scores did not significantly predict any of the leadership styles. 


\section{Discussion}

We found that the KAI inventory can be largely predicted (corrected multiple $R=.82$ ) by personality and gender. Furthermore, the KAI did not predict variance in leadership measures. That the KAI overlaps with personality followed our theoretical arguments; close scrutiny of the KAI items suggests they have much in common with those of big five models. Our results imply that the KAI's uniqueness and utility for predicting individual outcomes is very limited.

Why have results such as ours not surfaced sooner? Kozhevnikov (2007, p. 478), who is sympathetic to this stream of research mentioned "almost no research has been done recently to examine the relations among cognitive styles and the five basic personality factors." Such situations invariably cause a science-practice divide, particularly concerning popular "alternative" individual difference models. Constructs must be thoroughly tested before they can assume their place in the nomological network of individual differences and used in practice.

Discussions regarding the utility of cognitive style have occurred before; however, they were mostly theoretical or based on minimal tests of discriminant and incremental validity. Many researchers have suggested that cognitive style is different from personality (e.g., Messick, 1996; Riding, 1997) or that it bridges personality and cognition (e.g., Messick, 1996; Sternberg \& Grigorenko, 1997). Kirton (1999, p. 120) also noted that "whether style is [or is not] a wholly integral part of personality theory is still a scholarly issue." We think not and future research should always use the best-validated controls to test whether style constructs are different from better-established and well-validated personality or intelligence models. At this time, it appears that there is no strong evidence supporting "style-like" measures (cf. Pashler et al., 2008).

Therefore, until more extensive studies are conducted, we strongly urge researchers to take precautionary measures when using the KAI questionnaire by controlling for personality in 
any predictive model; they should also correct for the effects of measurement error. As we demonstrated, traditional OLS models and bivariate correlations severely understate the true relations among constructs measured with error.

\section{Limitations and Future Research}

Our findings should be taken in light of certain limitations. First, we used students to examine whether the KAI could predict leadership outcomes. Although individual differences predict leader outcomes both in student and non-student samples in similar ways (Judge et al, 2002) there are qualitative differences between students and employed adults.

Also, despite the fact that the leadership task under which we put the groups was challenging and relatively realistic, the temporary nature of the experiment and the setting did not fully mimic the types of dynamics that occur between actual leaders and their teams. For instance, it is possible that only conscientiousness was related to the active forms of leadership (transformational and contingent reward leadership) because the nature of the task was such that only leaders who were precise and systematic in their information search and integration strategies would succeed in influencing team members on the decision-making task.

Nevertheless, we doubt field studies will contradict our results given that experimental results are rather congruent with field experiments (Anderson, Lindsay, \& Bushman, 1999). Although we are confident that the results regarding the relation of personality to cognitive style will hold in other settings, we hope that future research will use robust tests in settings where leadership is observed in a more natural environment to establish if cognitive style predicts leadership.

Finally, even if we have reported data that is similar to the norms of the personality and KAI inventories we used, future research should seek to confirm these findings in English- 
speaking settings. We expect that our findings will be confirmed because the KAI and NEO-PI inventories have shown good cross-country stability.

\section{Conclusions}

Research in the cognitive style domain appears to have reached an "impasse" (Kozhevnikov, 2007, p. 464) and is currently “dormant” (Mayer, 2008); our findings are certainly not making the situation more optimistic. Although tempting, our intention is not to call for a moratorium on this line of research. Perhaps research on style constructs will be wound down if our results are replicated in larger-scale settings.

We think that the "writing is on the wall" insofar as "style" constructs are concerned (cf. Pashler, et al., 2008). However, we encourage researchers to continue gathering data on cognitive style, personality, and outcomes in the hope that meta-analytic studies, correcting for methodological artifacts and measurement error, are conducted to show the extent to which "style" overlaps with personality. Only rigorous research will definitively answer (and this probably to the negative) the title of Sternberg and Grigorenko's (1997) article: "Are cognitive styles still in style?" 


\section{REFERENCES}

Amabile, T. M., Hill, K. G., Hennessey, B. A., \& Tighe, E. M. (1994). The Work Preference Inventory - Assessing intrinsic and extrinsic motivational orientations. Journal of Personality and Social Psychology, 66, 950-967.

Anderson, C. A., Lindsay, J. L., \& Bushman, B. J. (1999). Research in the psychological laboratory: Truth or triviality? Current Directions in Psychological Science, 8, 3-9. Antonakis, J., Avolio, B. J., \& Sivasubramaniam, N. (2003). Context and leadership: An examination of the nine-factor Full-Range Leadership Theory using the Multifactor Leadership Questionnaire. The Leadership Quarterly, 14, 261-295.

Antonakis, J., Bendahan, S., Jacquart, P., \& Lalive, R. (2010). On making causal claims: A review and recommendations. The Leadership Quarterly, 21. 1086-1120.

Antonakis, J., \& Dietz, J. (2011). Looking for Validity or Testing It? The Perils of Stepwise Regression, Extreme-Scores Analysis, Heteroscedasticity, and Measurement Error. Personality and Individual Differences, 50(3), 409-415.

Baer, M., Oldham, G. R., \& Cummings, A. (2003). Rewarding creativity: when does it really matter? The Leadership Quarterly, 14, 569-586.

Bass, B. M. (1985). Leadership and performance beyond expectations. New York: Free Press.

Bass, B. M., \& Avolio, B. J. (1995). MLQ Multifactor leadership questionnaire for research: Permission set. Redwood City, CA: Mindgarden.

Bollen, K. A. (1989). Structural equations with latent variables. New York: John Wiley \& Sons.

Chan, D. (1996). Cognitive misfit of problem-solving style at work: A facet of personorganization fit. Organizational Behavior and Human Decision Processes, 68, 194-207. 
Chilton, M. A., Hardgrave, B. C., \& Armstrong, D. J. (2005). Person-job cognitive style fit for software developers: The effect on strain and performance. Journal of Management Information Systems, 22, 193-226.

Church, A. H., \& Waclawski, J. (1998). The relationship between individual personality orientation and executive leadership behaviour. Journal of Occupational and Organizational Psychology, 71, 99-125.

Costa, P. T., \& McCrae, R. R. (1992). NEO-PI professional manual. Lutz, FL: Psychological Assessment Resources.

Dawes, P. L., Lee, D. Y., \& Dowling, G. R. (1998). Information control and influence in emergent buying centers. Journal of Marketing, 62, 55-68.

Farmer, S. M., Tierney, P., \& Kung-McIntyre, K. (2003). Employee creativity in Taiwan: An application of role identity theory. Academy of Management Journal, 46, 618-630.

Gallivan, M. J. (2003). The influence of software developers' creative style on their attitudes to and assimilation of a software process innovation. Information \& Management, 40, 443465.

Garfield, M. J., Taylor, N. J., Dennis, A. R., \& Satzinger, J. W. (2001). Research report: Modifying paradigms - Individual differences, creativity techniques, and exposure to ideas in group idea generation. Information Systems Research, 12, 322-333.

Isaksen, S. G., Babij, B. J., \& Lauer, K. J. (2003). Cognitive styles in creative leadership practices: Exploring the relationship between level and style. Psychological Reports, 93, 983-994 
Janssen, O., de Vries, T., \& Cozijnsen, A. J. (1998). Voicing by adapting and innovating employees: An empirical study on how personality and environment interact to affect voice behavior. Human Relations, 51, 945-967.

Judge, T. A., Bono, J. E., Ilies, R., \& Gerhardt, M. W. (2002). Personality and leadership: A qualitative and quantitative review. Journal of Applied Psychology, 87, 765-780.

Judge, T. A., \& Piccolo, R. F. (2004). Transformational and transactional leadership: A metaanalytic test of their relative validity. Journal of Applied Psychology, 89, 755-768.

Keller, R. T. (1986). Predictors of the performance of project groups in research-anddevelopment organizations. Academy of Management Journal, 29, 715-726.

Keller, R. T., \& Holland, W. E. (1978). Individual characteristics of innovativeness and communication in research and development organizations. Journal of Applied Psychology, 63, 759-762.

Keller, R. T., \& Holland, W. E. (1983). Communicators and innovators in research and development organizations. Academy of Management Journal, 26, 742-749.

Kirton, M. J. (1976). Adaptors and Innovators: A description and measure. Journal of Applied Psychology, 61, 622-629.

Kirton, M.J. (1999). Kirton Adaption-Innovation Inventory: User's Manual. (1999). Suffolk, UK: Occupational Research Centre.

Kirton, M. J. (2003). Adaption-Innovation in the context of diversity and change. East Sussex: Routledge.

Kolb, A. Y. \& Kolb, D. A. (2005). Learning styles and learning spaces: Enhancing experiential learning in higher education. Academy of Management Learning \& Education, 4, 193212. 
Kozhevnikov, M. (2007). Cognitive styles in the context of modem psychology: Toward an integrated framework of cognitive style. Psychological Bulletin, 133, 464-481.

Lowe, K. B., \& Gardner, W. L. (2000). Ten years of The Leadership Quarterly: Contributions and challenges for the future. The Leadership Quarterly, 11, 459-514.

Mayer, R. E. (2008). Incorporating Individual Differences Into the Science of Learning Commentary on Sternberg et al. (2008). Perspectives on Psychological Science 3, 507 508.

Messick, S. (1996). Bridging cognition and personality in education: The role of style in performance and development. European Journal of Personality, 10, 353-376.

Palmer, J. (1991). Scientists and information II personal factors in information behavior. Journal of Documentation, 47, 254-275.

Pashler, H., McDaniel, M., Rohrer, D., \& Bjork, R. (2008). Learning Styles: Concepts and Evidence. Psychological Science in the Public Interest, 9, 105-119.

Pittenger, D. J., (1993). The utility of the Myers-Briggs Type indicator. Review of Educational Research, 63, 467-488.

Podsakoff, P. M., \& Organ, D. W. (1986). Self-reports in organizational research: Problems and prospects. Journal of Management, 12, 531-544.

Riding, R. J. (1997). On the nature of cognitive Style. Educational Psychology, 17, 29-49.

Sadler-Smith, E. (1998). Cognitive style: Some human resource implications for managers. International Journal of Human Resource Management, 9, 185-202.

Scheffler, I. (1991). In praise of cognitive emotions. New York: Routledge.

Schulte, M. J., Ree, M. J., \& Carretta, T. R. (2004). Emotional intelligence: Not much more than $g$ and personality. Personality and Individual Differences, 37, 1059-1068. 
Sternberg, R. J. (1988). Mental self-government - a theory of intellectual styles and their development. Human Development, 31, 197-221.

Sternberg, R. J., \& Grigorenko, E. L. (1997). Are cognitive styles still in style? American Psychologist, 52, 700-712.

Tierney, P., Farmer, S. M., \& Graen, G. B. (1999). An examination of leadership and employee creativity: The relevance of traits and relationships. Personnel Psychology, 52, 591-620.

Tullet, A. D. \& Kirton, M. J. (1995). Further evidence for the independence of AdaptiveInnovative (A-I) cognitive style from national culture. Personality and Individual Differences, 19, 393-396.

Vishwanath, A. (2005). Impact of personality on technology adoption: An empirical model. Journal of the American Society for Information Science and Technology, 56, 803-811.

Wonderlic (2002). Wonderlic Personnel Test \& Scholastic Level Exam: User's manual. Libertyville, IL: Wonderlic Personnel Test, Inc. 
Table 1: Descriptive Statistics and Correlations among KAI, Personality, and Key Variables (Study 1)

\begin{tabular}{|c|c|c|c|c|c|c|c|c|c|c|c|c|c|c|}
\hline & & $\mathrm{M}$ & SD & 1 & 2 & 3 & 4 & 5 & 6 & 7 & 8 & 9 & 10 & 11 \\
\hline 1. & KAI & 91.15 & 15.67 & .88 & & & & & & & & & & \\
\hline 2. & Neuroticism & 89.93 & 21.49 & -.23 & .83 & & & & & & & & & \\
\hline 3. & Extraversion & 120.71 & 17.80 & .39 & -.22 & .70 & & & & & & & & \\
\hline 4. & Openness & 113.94 & 19.36 & .40 & .01 & .33 & .68 & & & & & & & \\
\hline 5. & Agreeableness & 107.55 & 18.05 & -.29 & .14 & -.03 & .11 & .74 & & & & & & \\
\hline 6. & Conscientiousness & 121.56 & 19.61 & -.32 & -.31 & .07 & -.18 & -.10 & .83 & & & & & \\
\hline 7. & Gender & .38 & .49 & -.13 & .35 & -.08 & .02 & .24 & -.01 & - & & & & \\
\hline 8. & Age & 20.89 & 1.40 & .03 & -.08 & -.16 & -.04 & .02 & -.04 & .03 & - & & & \\
\hline 9. & Language & .79 & .41 & -.11 & .07 & -.04 & -.08 & .10 & .06 & .04 & -.22 & - & & \\
\hline & Nationality & .73 & .45 & -.03 & .08 & -.05 & -.02 & .04 & .01 & -.01 & .04 & .24 & - & \\
\hline 11. & IQ & 28.66 & 5.35 & .01 & -.15 & -.09 & -.01 & -.19 & .06 & -.09 & -.14 & .08 & .18 & .80 \\
\hline
\end{tabular}

Notes. $\mathrm{N}=210$ (having full observations). Numbers on the diagonals are reliabilities (we constrained the reliability for IQ to .80 the errors-invariables regression models). Gender is coded 1 for females (else 0), Nationality is coded 1 for Swiss (else 0), French language is coded 1 for French (else 0). High (or low) KAI scores indicate an innovative (or adaptive) style; for $r>|.13|, \mathrm{p}<.05 ; \mathrm{r}>|.17|, \mathrm{p}<.01 ; \mathrm{r}>|.22|, \mathrm{p}<.001$. 
Table 2: Predicting KAI scores--Standardized Regression Estimates (Study 1)

\begin{tabular}{|c|c|c|c|c|}
\hline VARIABLES & $\begin{array}{l}(1)^{\mathrm{a}} \\
\text { OLS }\end{array}$ & $\begin{array}{l}(2)^{\mathrm{a}, \mathrm{c}} \\
\mathrm{OLS}\end{array}$ & $\begin{array}{l}(3)^{b} \\
\text { EIV }\end{array}$ & $\begin{array}{l}(4)^{b, c} \\
\text { EIV }\end{array}$ \\
\hline Neuroticism & $\begin{array}{l}-.29 * * * \\
(-4.72)\end{array}$ & $\begin{array}{l}-.32 * * * \\
(-3.74)\end{array}$ & $\begin{array}{l}-.40 * * * \\
(-5.51)\end{array}$ & $\begin{array}{l}-.44 * * * \\
(-3.79)\end{array}$ \\
\hline Extraversion & $\begin{array}{l}.27 * * * \\
(4.66)\end{array}$ & $\begin{array}{l}.28 * * * \\
(3.18)\end{array}$ & $\begin{array}{l}.30 * * * \\
(3.22)\end{array}$ & $\begin{array}{r}.32 * \\
(1.94)\end{array}$ \\
\hline Openness & $\begin{array}{l}.28 * * * \\
(5.19)\end{array}$ & $\begin{array}{l}.30 * * * \\
(3.81)\end{array}$ & $\begin{array}{l}.40 * * * \\
(4.59)\end{array}$ & $\begin{array}{l}.42^{* * *} \\
(3.32)\end{array}$ \\
\hline Agreeableness & $\begin{array}{c}-.34 * * * \\
(-6.32)\end{array}$ & $\begin{array}{l}-.38 * * * \\
(-5.15)\end{array}$ & $\begin{array}{l}-.52 * * * \\
(-7.86)\end{array}$ & $\begin{array}{l}-.62 * * * \\
(-6.72)\end{array}$ \\
\hline Conscientiousness & $\begin{array}{l}-.43 * * * \\
(-7.57)\end{array}$ & $\begin{array}{l}-.39 * * * \\
(-4.85)\end{array}$ & $\begin{array}{c}-.56^{* * * *} \\
(-8.86)\end{array}$ & $\begin{array}{l}-.50 \text { **** } \\
(-5.25)\end{array}$ \\
\hline Gender & $\begin{array}{r}.06 \\
(1.05)\end{array}$ & $\begin{array}{c}.04 \\
(.53)\end{array}$ & $\begin{array}{l}.13 * * * \\
(2.74)\end{array}$ & $\begin{array}{l}.16^{* *} \\
(2.24)\end{array}$ \\
\hline Age & $\begin{array}{r}.05 \\
(.81)\end{array}$ & $\begin{array}{r}.04 \\
(.50)\end{array}$ & $\begin{array}{r}.04 \\
(.82)\end{array}$ & $\begin{array}{c}.07 \\
(.84)\end{array}$ \\
\hline Nationality & $\begin{array}{r}.04 \\
(.66)\end{array}$ & $\begin{array}{r}.06 \\
(.79)\end{array}$ & $\begin{array}{r}.06 \\
(1.34)\end{array}$ & $\begin{array}{r}.08 \\
(1.27)\end{array}$ \\
\hline Language & $\begin{array}{r}-.00 \\
(-.08)\end{array}$ & $\begin{array}{c}.01 \\
(.10)\end{array}$ & $\begin{array}{r}.03 \\
(.73)\end{array}$ & $\begin{array}{r}.08 \\
(1.23)\end{array}$ \\
\hline IQ & $\begin{array}{l}-.03 \\
(-.63)\end{array}$ & $\begin{array}{c}-.07 \\
(-.98)\end{array}$ & $\begin{array}{r}-.09 \\
(-1.43)\end{array}$ & $\begin{array}{r}-.15 \\
(-1.56)\end{array}$ \\
\hline Constant & $\begin{array}{r}-.01 \\
(-.28)\end{array}$ & $\begin{array}{c}.12 \\
(1.66)\end{array}$ & $\begin{array}{c}-.01 \\
(-.31)\end{array}$ & $\begin{array}{r}.09 \\
(1.59)\end{array}$ \\
\hline $\mathrm{F}(10,199)$ & $20.26 * *$ & & $30.01 * * *$ & \\
\hline $\mathrm{F}(10,118)$ & & $12.18 * * *$ & & $18.26 * * *$ \\
\hline Observations & 210 & 129 & 210 & 129 \\
\hline Multiple R & .71 & .71 & .82 & .82 \\
\hline R-squared & .50 & .51 & .67 & .67 \\
\hline Adj. R-Square & .47 & .47 & .65 & .64 \\
\hline
\end{tabular}

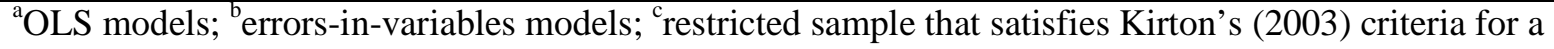

valid response set; Hausman tests indicate that the coefficients from Models 1 and 2 were not

significantly different $\chi^{2}(10)=3.66, p>.10$, as was the case for Models 3 and $4 \chi^{2}(10)=9.16, p>.10$.

Given that the estimates were empirically indistinguishable, we retained the full sample for all analyses.

Gender is coded 1 for females (else 0 ), Nationality is coded 1 for Swiss (else 0), French language is coded 1 for French (else 0). N = 210; t-statistics for parameter tests in parentheses; $* * * \mathrm{p}<.01,{ }^{* *} \mathrm{p}<.05, * \mathrm{p}<$ .10 
Table 3: Descriptive Statistics and Correlations among KAI, Personality, Leadership, and Key Variables for Rated Leaders (Study 2)

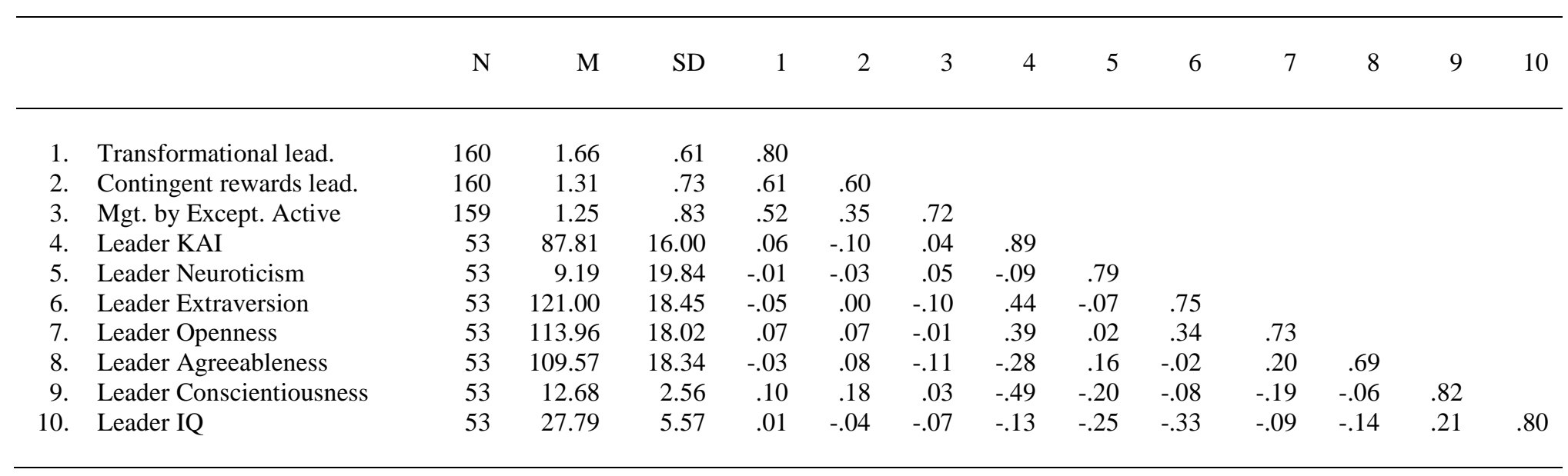

Notes: 160 Participants rated 53 leaders (variables 1, 2, and 3); we control for clustering in the regression analyses. Variables 4 to 10 represent the leaders' selfratings . Numbers on the diagonals are reliabilities. 
Appendix: Overview of Articles using the KAI in high-impact peer-reviewed journals

Journal Name Authors, date Variables studied

\begin{tabular}{|c|c|c|}
\hline Academy of Management Journal & $\begin{array}{l}\text { Farmer, Tierney, \& Kung- } \\
\text { McIntyre, } 2003\end{array}$ & $\begin{array}{l}\text { Employee creativity; Creativity role identity; Perceived coworker creativity expectations; } \\
\text { Self-views of creative behavior; Exposure to U.S. culture; Educational level; Psychological } \\
\text { job complexity; Perceived organizational valuing of creativity }\end{array}$ \\
\hline Academy of Management Journal & Keller \& Holland, 1983 & $\begin{array}{l}\text { Communication of information; Innovation ; Self-esteem; Need for clarity; Patents; } \\
\text { Publications; Education; Periodicals read; Job level; Centrality }\end{array}$ \\
\hline Academy of Management Journal & Keller, 1986 & $\begin{array}{l}\text { Project performance ; Group cohesiveness; Physical Distance; Job satisfaction; Type of } \\
\text { R\&D }\end{array}$ \\
\hline Human Relations & $\begin{array}{l}\text { Janssen, de Vries, \& Cozijnsen, } \\
1998\end{array}$ & Employee likelihood to voice ideas; Work satisfaction; Voice manager's effectiveness \\
\hline Information Systems Research & $\begin{array}{l}\text { Garfield, Taylor, Dennis, \& } \\
\text { Satzinger, } 2001\end{array}$ & $\begin{array}{l}\text { No. of novel ideas; MBTI; Creativity technique; Contribution from others; Overall } \\
\text { creativity }\end{array}$ \\
\hline Journal of Applied Psychology & Keller \& Holland, 1978 & $\begin{array}{l}\text { Innovativeness/technological communication; Administrative communication; Existence } \\
\text { need desire; Relatedness desire; Growth need desire; Need for clarity; Self-esteem; Locus } \\
\text { of control }\end{array}$ \\
\hline Journal of Documentation & Palmer, 1991 & Information behavior; Learning Styles \\
\hline $\begin{array}{l}\text { Journal of Management } \\
\text { Information Systems }\end{array}$ & $\begin{array}{l}\text { Chilton, Hardgrave, \& Armstrong, } \\
2005\end{array}$ & Strain; Performance; Person-Job fit \\
\hline Journal of Marketing & Dawes, Lee, \& Dowling, 1998 & $\begin{array}{l}\text { Influence on the selection of a supplier control over the flow of interpersonal information; } \\
\text { Formalization; Decentralization; Stakeholding; Participation in the buying process; }\end{array}$ \\
\hline $\begin{array}{l}\text { Journal of Occupational and } \\
\text { Organizational Psychology }\end{array}$ & Chan, 1996 & Job performance; Turnover ; Work context; Cognitive misfit \\
\hline $\begin{array}{l}\text { Journal of Personality and Social } \\
\text { Psychology }\end{array}$ & $\begin{array}{l}\text { Amabile, Hill, Hennessey, \& } \\
\text { Tighe, } 1994\end{array}$ & $\begin{array}{l}\text { Work Preference; Social desirability; Motivation: Causality orientation, Student interest and } \\
\text { experience; Orientation toward the past; Need for Cognition; SII; MBTI; Adult playfulness; } \\
\text { and Cognitive playfulness; Environment perception: CEI; WEI; WES; Creativity measures; } \\
\text { Creative personality; }\end{array}$ \\
\hline $\begin{array}{l}\text { Journal of the American Society } \\
\text { for Information Science and } \\
\text { Technology }\end{array}$ & Vishwanath, 2005 & $\begin{array}{l}\text { Likelihood of adoption; Technological innovativeness; Prior technology ownership; } \\
\text { Cosmopolite; Integrated social networks; Information search strategies; Media use; Global } \\
\text { innovativeness; Tolerance for novelty; Tolerance for complexity; Tolerance for Insolubility }\end{array}$ \\
\hline The Leadership Quarterly & Baer, Oldham, \& Cummings, 2003 & $\begin{array}{l}\text { Creativity; Extrinsic rewards; Education; Organizational Tenure; Sex; Race; Position; Job } \\
\text { complexity }\end{array}$ \\
\hline Personnel Psychology & Tierney, Farmer, \& Graen, 1999 & $\begin{array}{l}\text { Employee creative performance; Intrinsic motivation; LMX; Leader; Leader intrinsic } \\
\text { motivation; Educational level; Organizational tenure; Division; Hierarchical level; LMX ; } \\
\text { Intrinsic motivation; Leader intrinsic motivation }\end{array}$ \\
\hline
\end{tabular}

